\title{
The Impact of Institutional Environment on the Company Liquidity Pricing
}

\author{
Du Jinmin \\ Ji'nan University \\ Guangzhou, China \\ tjmdu@jnu.edu.com \\ Ye Yamin \\ Ji'nan University \\ Guangzhou, China \\ yeyamin1993@163.com
}

\author{
Ye Xiaodong \\ Guangzhou Development Group \\ Guangzhou, China \\ 648444016@qq.com
}

\begin{abstract}
The aim of this paper is to study how the institutional environment affects the company liquidity pricing, and the research objects are listed companies. We study the objects comprehensively by theoretical derivation and apply the institutional environment into the model, which is set for the liquidity pricing problem of listed companies. Our findings indicate that changes of policies will promote the company liquidity price, and the wider range it changes, the higher prices will be. This case demonstrates that to improve the value of company's liquidity, we can continuously make the institutional environment better. This paper illustrates a systemic way of improving the value of incorporation liquidity, i.e. improving the institutional environment.
\end{abstract}

Keywords-Institutional Environment; Company Liquidity Pricing; Impact of Random Liquidity; Value of Liquidity; Changes of Lolicy

Chun-feng Wang (2010) does a further optimized disposal for relaxing the market assumption based on ACW model, i.e. companies can finance through equity and debt without consideration of external hedge risk, to explore the cash holding strategy which is applied by companies to respond to the liquidity hedge risk, based on no changes of liquidity preference [1]. They argue that if a market does not contain the system of external hedge risk, cash flowing from hedging will fluctuate smaller than that from no hedging behavior. From Liquidity Preference, optimal cash holding in the model should be more than that from ACW. They think ACW underestimates the optimal cash holding because it does not consider that companies with financing restrictions can't hedge the risk of future cash. Foucault and Fresard (2012) form a useful conclusion from in-depth analysis of the strategic incentive, which considers that advantages of holding a lot of cash will appear with rare cash flowing and high-criterion entrance to market [2]. Principal-agent Theory deems that fifth management layer has the motivation and shareholding co-operative system will be a common form of management for modern companies, in which managers are in charge of daily business and management; the board is responsible for making strategic plan. This causes agency problem due to the separation of ownership and management. The purposes of owners and managers are different while managers usually refuse to issue dividends and remain earnings for their own benefits.

For the research of CEO's effect of complement incentive, Yixin Liu, David C Mauer (2011) show the positive correlation between CEO's risk tolerance (vega) and cash holding while shareholders have the opposite[3]. So their study further illustrates that creditors certainly expect that higher vega companies suffer more risk, which leads to addition of asset's liquidity.

Yanchao Wang (2010) indicates in the study that root cause of cash holding is financing restriction and the existence of premium cash, which usually cause agency problem [4]. Marginal value of cash declines with gradual addition of premium cash. Using A-share companies in China as research objects, the study finds that add 1 unit cash, cash value will decline 0.82 commonly while ownership concentration changes $10 \%$, marginal value of cash will increase 0.2185 . Among the companies of which cash holding to assets ratio catches up to $10 \%$, marginal value of private enterprises' cash ranks first; the enterprises directly under the central government rank the second and the last one are district companies. Studying in the nonfinancial listed companies in China, Boyan Liu and Liyan Han (2011 focus on the relations of financing restriction, uncertainty, corporation governance and corporate liquidity [5]. They find that corporation liquidity has a positive relationship with financing restriction, uncertainty and corporation liquidity, also the differences of them are huge. For example, the differences of corporation value are double between a corporation with financing restriction or not under 1-unit corporation liquidity.

Bin Xi (2011) does a compressively research about affecting factors for the value of cash holdings [6]. Jian Liao (2011) applies the way of compound option pricing into research on the analysis of pricing for the incorporation liquidity [7]. Studying in the pricing analysis of Chinese equity open-ended funds liquidity, Si Sun (2012) also uses the way of option pricing[8]. Laurent Fresard and Carolina Salva (2010) study American multinational corporations and major in investigating behiviors and procedures whether companies' internal managers turn companies' cash into private benefits by transferring risk [9]. The result illustrates that benefits 
from investment of premium cash in American multinational corporations are more, and the root because of it accounts for not only the information disclosure system and laws and regulations, but also the government's rigid informal supervision for listed companies in America. In this paper, we will study the problem in the way of analysis and framework from Tirole (2011).

To study the incorporation liquidity pricing under the institutional environment, we put the system of obligation, property rights system and the companies' liquidity into sustained investment model and derivate it. Hypotheses are proposed as follows:

Hypothesis 1: Borrower company has a project in stage 0 and needs investment $I$ with company's own asset $A(0<A<I)$, so it needs investment from external investors $I-A$, in which $I$ and $A$ can be cash or liquid securities.

Hypothesis 2: After stage 0 but before stage1, the government adopts a policy $\tau$ that is profitable and $\tau \geq 0$, borrower company should be responsible totally for each unit investment cost $\hat{r}(\tau)$, and at this time, the success probability of project investment is $p+\tau$. For convenience of derivation, it can be hypothesized that:

$$
a=\tau / p_{H}
$$

At this time,

$$
r(a)=\hat{r}\left(p_{H} a\right)=\hat{r}(\tau)
$$

Hypothesis 3: the borrower company will face the random liquidity shock $\rho_{\omega}$ in stage 1 and $\omega=L, H$, i.e. the random liquidity shock can be divided into two kinds: lowly intensive random liquidity shock, at this time, $\rho_{\omega}=\rho_{L}$; the highly intensive random liquidity shock, at this time, $\rho_{\omega}=\rho_{H}$. The random liquidity shock means that it is faced by the company under the unit investment.

Hypothesis 4: The probability of the occurrence of lowly intensive random liquidity shock is $f_{L}$, and the probability of the occurrence of highly intensive random liquidity shock is $f_{H}$. What's more:

$$
f_{L}+f_{H}=1
$$

Hypothesis 5: the borrower company will reserve current assets in stage 0 to respond to the random liquidity shock which may happen in stage 1 . At the moment, each unit current asset can bring the marginal utility $S_{\omega}$, and $\omega=L, H$, i.e. under the lowly intensive random liquidity shock, marginal utility of each unit liquidity is

$S_{L}$ held by borrower company; under the highly intensive random liquidity shock, marginal utility of each unit liquidity is $S_{H}$ held by borrower company;
Hypothesis 6: Under the lowly intensive random liquidity shock, and the borrower company can handle a situation with ease. So it has no demand for external liquidity, $s_{L}=1$; Under the highly intensive random liquidity shock, it cannot handle by itself, so it needs external liquidity, and at this time, $s_{H}>1$.

Hypothesis 7: Two kinds of companies called conventional and unconventional companies can be assumed for simplifying the model. For two kinds of companies, they both have $\rho_{L}=0$. Before government policy changes, expected certifiable income of project investment is $\rho_{0}$, and expected total income of project investment is $\rho_{1}$; after government policy changes, expected certifiable income of project investment is $(1+a) \rho_{0}$, and expected total income of project investment is $(1+a) \rho_{1}$. Conventional companies demand liquidity when facing highly intensive random liquidity shock, i.e.:

$$
0=\rho_{L}<(1+a) \rho_{0}<\rho_{H}<(1+a) \rho_{1}
$$

And for unconventional companies, it can supply liquidity when facing highly intensive random liquidity shock, i.e.:

$$
0=\rho_{L}<\rho_{H}<(1+a) \rho_{0}<(1+a) \rho_{1}
$$

Because of the small proportion for unconventional companies, total liquidity is short when they face the highly intensive random liquidity shock.

Hypothesis 8: Given that under no consideration of project's initial finance, borrower company's net earnings is $y_{\omega}$, and $\omega=L, H$, i.e. net earnings under lowly intensive random liquidity shock is $y_{L}$; it is $y_{H}$ under highly intensive random liquidity shock.

Hypothesis 9: For the finity of external investment, the condition as follows should be satisfied:

$$
f_{L}\left[(1+a) \rho_{0}-\rho_{L}\right]=f_{L}(1+a) \rho_{0}<1
$$

Under Tirole's framework of analysis, time sequence of actions is as shown in Figure 1.

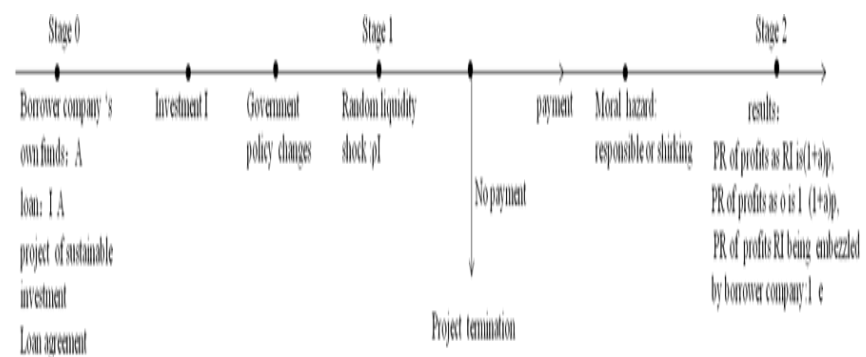

Figure 1. Time Sequence of Actions 
It can be seen from Fig.1 that to respond to random liquidity shock in stage 1 , company may reserve current assets ${ }^{[10]}$. At this time, company need to afford the cost to gain current assets, and this will cause liquidity premium. We can see clearly that changes of government policy affect these procedures while the contracts to be enforced in stage 2 do not. So the conclusion is that system of obligation does not affect the incorporation liquidity pricing while property rights system will do so.

According to hypothesis condition, the borrower company's net earning can be calculated with no consideration of initial financing:

TABLE I RESULTS UNDER RANDOM LIQUIDITY SHOCK

\begin{tabular}{|l|l|l|}
\hline $\mathrm{y}_{\mathrm{L}}>0$ & $\begin{array}{l}\text { Borrower company which is } \\
\text { under the low-intensity random } \\
\text { liquidity shock }\end{array}$ & $\begin{array}{l}\text { Can supply } \\
\text { liquidity }\end{array}$ \\
\hline $\mathrm{y}_{\mathrm{L}}<0$ & $\begin{array}{l}\text { Borrower company which is } \\
\text { under the low-intensity random } \\
\text { liquidity shock }\end{array}$ & $\begin{array}{l}\text { Have liquidity } \\
\text { demand }\end{array}$ \\
\hline $\mathrm{y}_{\mathrm{H}}>0$ & $\begin{array}{l}\text { Borrower company which is } \\
\text { under the high-intensity random } \\
\text { liquidity shock }\end{array}$ & $\begin{array}{l}\text { Can supply } \\
\text { liquidity }\end{array}$ \\
\hline $\mathrm{y}_{\mathrm{H}}<0$ & $\begin{array}{l}\text { Borrower company which is } \\
\text { under the high-intensity random } \\
\text { liquidity shock }\end{array}$ & $\begin{array}{l}\text { Have liquidity } \\
\text { demand }\end{array}$ \\
\hline
\end{tabular}

At this time, external investors' income from expected project in stage 1 is:

$$
E(y)=f_{L} y_{L}+f_{H} y_{H}
$$

And in stage 0 , the market value of borrower company' $s$ current assets is:

$$
E(y s)=f_{L} y_{L}+f_{H} y_{H} s_{H}
$$

The borrower company will face the budget restrictions as follows:

$$
E(y s)=f_{L} y_{L}+f_{H} y_{H} s_{H} \geq I-A
$$

So according to deduction, liquidity premium will happen in stage 0 , i.e.:

$$
v=f_{H} y_{H}\left(s_{H}-1\right)
$$

$v$ in the above formula represents the unit liquidity value under the intensive random liquidity shock.

For conventional companies, $y_{H}<0$, so liquidity premium is negative; but for unconventional companies, $y_{H}>0$, so liquidity premium is positive.
External investors' profit is 0 , so the budget restriction must apply equal sign, i.e.:

$$
E(y s)=E(y)+v=I-A
$$

The above formula equals to:

$$
E(y)=E(y s)-v=(I-A)-v
$$

The left side of above formula represents external investors' total expected return in stage 1, and the right side represents external investors' total investment. For a conventional company, it needs liquidity when facing up to intensive random shock. The investment on the right side of the formula contains two parts, one part is external investors' initial investment and the other part is the liquidity premium which is paid to obtain the liquidity in stage 1 .

The claim right of the unit liquidity value from borrower company is:

$$
q=E(y s) / E(y)=\left(f_{L} y_{L}+f_{H} y_{H} s_{H}\right) /\left(f_{L} y_{L}+f_{H} y_{H}\right)
$$

q means external investors are willing to afford the unit current asset value from premium (or discount) in stage 1 when having net earnings.

$$
\begin{gathered}
y_{L} 、 y_{H} \text { can be calculated in a standard way, i.e.: } \\
\bar{y}_{L}=y_{L} / E(y)=y_{L} /\left(f_{L} y_{L}+f_{H} y_{H}\right) \\
\bar{y}_{H}=y_{H} / E(y)=y_{H} /\left(f_{L} y_{L}+f_{H} y_{H}\right)
\end{gathered}
$$

This kind of standard calculation makes net earnings from borrower company which do not consider initial loan have unit expectation. The liquidity price $q$ in stage 1 can be shown further:

$$
q=f_{H} \bar{y}_{H}\left(s_{H}-1\right)+1
$$

Because conventional companies have a demand for liquidity when facing the highly intensive random liquidity shock, their each unit claim right has a liquidity discount, i.e. $q<1$; But for the unconventional companies, it happens the opposite, i.e. $q>1$.

According to the ideology of LAMP model held by Tirole, we can explain the reasons why the value of unit claim right can be considered as the price of liquidity assets. For the conventional companies which need to respond to the highly intensive random liquidity shock in stage 1 , the price $q$ comes from the extra finance burden for acquiring the amount $\left(-\bar{y}_{H}>0\right.$ ) of unit net earnings. To ensure the promise, external investors need to buy so much liquidity in stage 0 when the liquidity premium $S_{H}-1$ occurs, which precisely offsets the liquidity discount $q^{-1}$. Therefore, the total cost of purchasing a 
conventional company is 1 . Because consumers' income cannot be ensured, this promise needs liquidity assets to be guaranteed.

Through the above series of analysis and assumptions, at last, we can gain the liquidity assets' price with revenue flowing arbitrarily in stage 1 : $q=\left\{f_{L}\left[(1+a) \rho_{0}-\rho_{L}\right]+f_{H}\left[(1+a) \rho_{0}-\rho_{H}\right] s_{H}\right\} /\left\{f_{L}\left[(1+a) \rho_{0}-\rho_{L}\right]+f_{H}\left[(1+a) \rho_{0}-\rho_{H}\right.\right.$ From the above formula, incorporation liquidity pricing is influenced by changes of government policies. Take the derivative of above formula, and we can get: $d q / d a=\rho_{0} f_{H} f_{L}\left(s_{H}-1\right)\left(\rho_{H}-\rho_{L}\right) /\left\{f_{L}\left[(1+a) \rho_{0}-\rho_{L}\right]+f_{H}\left[(1+a) \rho_{0}-\rho_{H}\right.\right.$ It can be known from the assumption:

$$
d q / d a>0
$$

This means that changes of policies will improve the price of incorporation liquidity, and the wider range it changes, the higher prices will be. This demonstrates that to improve the value of company's liquidity, we can continuously improve the institutional environment.

\section{ACKNOWLEDGMENT}

This work was supported by the National Natural Science Foundation of China (NO.71173091)

\section{REFERENCES}

[1] WANG Chun-feng, ZHOU Min, FANG Zhen-ming. Research of listed companies' cash holding based on liquidity preference [J]. Journal of Management, 2010, 7(3).

[2] Foucault T, Fresard L. Cross listing investment sensitivity to stock price and the learning hypothetis[J]. Review of Financial Studies, 2012, 25(11):3305-3350.

[3] Liu Y, Mauer D C. Corporate cash holdings and CEO compensation incentives [J]. Journal of Financial Economics, 2011, 102(1):183-198.
[4] WANG Yan-chao. Financing Restriction, cash holding and cash value $[M]$. Press of Economy and Science, 2010.

[5] LIU Bo-yan, HAN Li-yan. Comparative research of incorporation liquidity management of listed companies in America and China-Findings of field features based on strategy of cash holding [J]. Economic Survey, 2011 (5): 145-150.

[6] XI Bin. Research on impact factors of cash value held by listed companies [D]. JiNan University, 2011.

[7] LIAO Jian. Research of incorporation liquidity pricing based on composite real option [J]. Technological Economics \& Management Research, 2011 (3): 102-106.

[8] SUN Si. Research of liquidity value of equity open-end fund in China [D]. JiNan University, 2012.

[9] Frésard L, Salva C. The Foreign Firm Discount [J]. Séminaire De 2 Recherche Université Catholique Du Sacré Coeur, 2010.

1b] Tirole J. Illiquidity and all its friends [J]. Journal of Economic Literature, 2011, 49(2): 287-325.

[11] SONG Li-ping, HU Xiao-xuan, Research on impact factors of liquidity risk on assets pricing [J]. Economic Research, 2011(35) : 130-131.

[12] LIU Chun-hong, ZHANG Wen-jun. Dynamic adjustment of business cycle fluctuation and finance restriction [J]. The Central University of Finance and Economics, 2013 (12).

[13] CHEN Yu-lu. The relationship between government and market during the development of finance [J]. Economic Study, 2014 (1) : 16-19.

[14] ZHENG Ling-yun. Research on the option pricing of incorporation liquidity [D]. JINAN University, 2007.

[15] ZHAN Rong-gui. Empirical research on the liquidity and liquidity fluctuation affecting the asset pricing [D]. TianJin University, 2012.

[16] HU Fang. Research on the liquidity risk and pricing of assets based on corporate governance [D]. HeBei University of Technology, 2011.

[17] LI Si-wen. Research on the relationship between the value of listed companies and stock liquidity [D]. XiaMen University, 2011.

[18] XIN Rui-jiang. Stock liquidity and the value of company --based on empirical test of Chinese listed companies [D].Peking University, 2010. 